\title{
Labour Intensity and Skill Gap in the Hospitality Sector: A Study in South India
}

\author{
K. R. Suprabha \\ School of Management, National Institute of Technology Karnataka, \\ Surathkal, India \\ Krishna Prasad \\ Justice K S Hegde Institute of Management, Nitte, India \\ Shridev \\ School of Management, National Institute of Technology Karnataka, \\ Surathkal, India
}

Received January 2017; Revised May 2017; Accepted June 2017

\begin{abstract}
Hospitality is all about offering warmth to someone who looks for help at a strange or unfriendly place. The hospitality industry has evolved from the basic food and accommodation industry and taken a very important position in almost all businesses. In fact, it has become a huge industry and has driven economies across the globe. The scope of hospitality/ service industry today is far more than one could have ever imagined a few years back. The study investigates the trends, constraints, and opportunities faced by the hospitality sector in selected districts of the three southern states of India, namely Karnataka, Kerala, and Tamil $\mathrm{Nadu}$, in light of the enormous changes taking place in the economy. Principal Component analysis, OLS regression, and non-parametric tests are applied to analyze the conditions and growth of the hospitality sector. The paper explores in detail these key trends, which impact both the hospitality industry as well as related sectors which make viable the travel experience. The study contributes to the discussion on the importance of the skill development and articulates the factors influencing the skill gap in the hospitality sector in the Indian context.
\end{abstract}

Keywords: Hospitality, tourism, skill gap.

Reference to this paper should be made as follows: Suprabha, K. R., Prasad, K., and Shridev. (2017). Labour Intensity and Skill Gap in Hospitality Sector: A Study in South India. ICPE Public Enterprise Half-Yearly Journal, 23(1), 84-110. 


\section{Introduction}

Tourism and hospitality are regarded as the fastest growing industry in the world, with India having a significant potential for developing the sector. The hospitality industry is one of the world's largest employers, and one of every six new businesses established in the world is a hospitality enterprise (Zorin, 2001). Hospitality is unquestionably one critical key success factor for service firms in today's new, experience-based economy (M.Ariffin, Maghzi, \& Aziz, 2011). In general, the hospitality sector is a wide-ranging classification of fields within the service industry which includes lodging, restaurants, event planning, theme parks, transportation, cruise line, and additional fields within the tourism industry (Weilbaker \& Crocker, 2001). The companies or organizations which provide food and/or drink and/or accommodation to people who are away from home are referred to as the hospitality industry (Chathoth \& Olsen, 2002). The concept of 'hospitality business' started when people started traveling away on business, and they needed a place away from home which could cater to all their needs. Today, hospitality has evolved from the basic food and accommodation industry and has taken a very important position in almost all businesses. In fact, it has become a huge industry and has driven economies across the globe. The scope of hospitality/ service industry today is far more than one could have ever imagined a few years back. The growth of the industry depends on the availability of the skilled manpower.

This study investigates the labour intensity and the skill gaps in the hospitality sector in South India. Further, we examine the factors which could explain the skill gap. The study contributes to the discussion on the importance of the skill development and articulates skill gaps at various levels of work. The paper also studies the relationship between skill gap articulation, improvement in infrastructure, growth in wages, age, leverage, investment, total employee strength, and skill gap.

\section{Literature Review}

The hospitality industry is one of the world's largest employers, and one of every six new businesses established in the world is a hospitality enterprise (Zorin, 2001). According to the World Travel \& Tourism Council(WTTC) and the International Labor Office (ILO), there is a worldwide consensus that employment generated by the tourism/hospitality industry can be substantial in many national economies, contributing to their economic growth and providing employment and income to people (Netter, 1998).

The human resources are one of the most important components for enhancing the productivity, especially in the tourism and hospitality sector. Productivity in the tourism and hospitality industry can be increased by studying the roles of 
changes in physical capital, human capital, innovation, and the competitive environment. Comprehensive results are obtained by using questionnaire-based interviews, business survey data analysis, and computable general equilibrium modeling. The results demonstrate the positive contribution that each of the productivity drivers can make to improving efficiency and welfare, notably increases in human capital and innovation (Blake, Sinclair, \& Soria, 2006).

They also indicate that a combined strategy incorporating all of the drivers is more effective than independently formulated policies. Georgiadis and Pitelis (2008) also found the empirical evidence of the relationship between human resources practices and the effectiveness of a firm to capitalize on investment in knowledge as measured by the returns to innovation and business development expenditure. Their findings suggest that businesses that receive support in the area of staff training and development, in HR planning and in staff recruitment and retention generate 100 per cent, 86 percent, and 134 percent more revenue per unit of money spent on innovation and business development compared to firms that do not receive such services. Blake, Sinclair, and Soria stated in 2006 that government organizations could collaborate to assist productivity increases, with specifically tailored measures for small firms.

\section{Nature of Work and Skills in Hospitality}

The job of hospitality and the skills that it requires display enormous diversity. In a sense, it comprises a very wide variety of jobs, the extent depending on the definition of the sector that is employed. Earlier research focused on hospitality work which was confined to areas that provide primarily food and beverage (Gabriel, 1988; Mars \& Nicod, 1984) and, to a small extent, accommodation. This was also covered in the studies by Guerrier and Deery (1998) and Wood (1997). Research into major areas of hospitality work, particularly those that have emerged with the expansion of services and functions in the area (front desk, leisure, entertainment, and reservations call centers) is much more poorly served, and this study draws on a limited range of work in these areas. The present area includes functions and tasks that exhibit considerable cross-over with work that falls out with normal definitions of hospitality in food and drinks manufacture, office administration, IT systems management, and specialist areas of sports and leisure. Indeed, it is fair to say that although there is long-standing debate as to whether the hospitality industry is 'unique' (Lashley \& Morrison, 2001; Mullins, 1981), there is little doubt that there is little that is unique about hospitality skills. Most of the skills that are employed within the sector also have relevance and application in other sectors of the economy. Those employed in areas where there is considerable overlap between skills and hospitality, such as the areas listed above, may well see themselves in terms of their generic skills area, rather than as part of the hospitality labour market. Some of these skills have been subject to separate assessment (Ecotec, 2001) in a manner that has value and cross-over 
implications for the hospitality sector. The characteristics and the organization of the hospitality industry are subject to on-going re-structuring and evolutionary change.

The skills profile of hospitality, in turn, is influenced by the labour market that is available to it, both in direct terms and via educational and training establishments. The meagre labour market characteristics in hospitality enforce plunging forces on the expectations of skills that employers have on their staff and thereby influences the nature and level of training that the educational system delivers. There is an evident cycle of down-skilling, not so much in response to the actual demands of hospitality work or of consumer expectations of what it can deliver, but as a result of the perceptions of potential employees and the expectations that employers have of them. Hospitality work is commonly considered in both the popular press and in research-based academic sources as dominated by a low skills profile (Wood, 1997; Shaw \& Williams, 2001). Bradley, Erickson, Stephenson, and Williams (2000) apply this epithet to the wider service or new economy in questioning the assumptions about a skills revolution in Britain, noting that "jobs commonly retain a low-skill character, especially in the fastest-growing sectors".

Athey (2004) maintained there is a contest for human capital, and when "the knowledge and skills of critical talent become scarce, recruiting wars erupt". He recommended that organizations identify the strategies, skills, and capabilities crucial to their current and future success, as well as the emerging workforce trends that will impact operations. The Lefever and Withiam (1998) study found that workforce recruitment and retention is the number one concern of hospitality professionals. Sourcing skilled labor for the hospitality industry is not only a domestic problem. The International Society of Hospitality Consultants listed a shrinking labor force as the number one human resource challenge facing the hospitality industry in 2006, and skills and labor shortage as the number one issue facing the hospitality industry in 2007 (Coy, 2006).

\section{Skill Characteristics Expected by Employers in the Hospitality Sector}

Skill is the ability to do something well (Soanes, Hawker, \& Elliot, 2006). Mish (1997) explained it as a capability and aptitude acquired through purposeful, orderly and sustained effort to smoothly and adaptively carry out complex activities or job functions involving ideas (cognitive skills), things (technical skills), and/ or people (interpersonal skills). Skills review analyses developed in about the 1980s when employers persuaded the government to challenge the autonomy of the training sector by reviewing and evaluating the traditional curricula because the employers felt that the curricula were not aligned to their needs (Bennett, Dunne, \& Carre, 2000; Hoddinott, 2004). Further, Diplari and Dimou (2010) explained that 
employees in tourism felt that the level of skills and knowledge offered in tertiary education was unsatisfactory and were not in line with their needs. They further stated that the hospitality and tourism industry requires specific job-related skills. In addition, that employers require hospitality staff to be quick learners, flexible, adaptable, and transformable (Bennett, 2010; Hjalager, 2003). Oliver et al. (1997) and Bennett et al. (2000) stated that employees need to demonstrate initiative, possess the ability to work well with others, solve problems routinely, and apply technology effectively. Bailey (1997) and Sinclair (1997) maintained that employees also need to be able to work independently with minimum supervision and to be creative. According to Bailey (1997) and Bennett et al. (2000), it is essential for employees to have acquired a broader knowledge and conceptual understanding of what their jobs entail for them to fit easily into the workplace culture. They further need to be able to acquire, organize, and interpret information.

Further, a study was conducted by Saayman and Geldenhuys (2003) among travel agents, tour operators, and tour guides and recognized the following as important in this field of study: computer skills, arithmetic skills, telephone skills, business writing, listening skills, language skills, negotiation skills, presentation skills, leadership and social skills, organizational skills, interpersonal skills, research skills, ethical and social responsibility skills, and cultural sensitivity skills. Some employers in tourism view communication skills as the top priority, followed by computer skills. Work experience with language skills was considered to be the least important. Employers generally rated transferable people skills above tourism knowledge when these were compared, and tourism knowledge was viewed as merely adding value.

Certain companies considered experience to be more important than a degreelevel qualification (Erasmus \& Breier, 2009; Peacock \& Ladkin, 2002). Besides the above, Jameson and Holden (2000) argued that graduates are regarded by many small and medium enterprise (SME) employers as being impractical, reluctant to get their hands dirty, slow to become productive and inclined to hold a poor view of what employment in an SME should be like.

Employers are of the opinion that the knowledge, skills, competencies, and values of new graduates may not be coordinated with the expectations of employers in this industry (Diplari \& Dimou, 2010; Erasmus \& Breier, 2009; Griesel \& Parker, 2009). Organizations struggle to find the quality and relevance of learners' prior training useful, regarding it as either 'too generic' or 'far removed' from the workplace realities (Swanson \& Holton, 2009). In order to meet the changing requirements of companies, tertiary institutions must design programmes that venture beyond content, thereby encouraging independent learning strategies whilst focusing on the ability to think systematically and redefine problems (Education, 2000). 
Schuurman (2004) observes that employers are not offered an opportunity to express their actual needs. He further stated that the employers should be engaged in all the progressions, as they could provide the most pertinent information on needs of training for tourism labour market and ultimately also be the ones to address the major inadequacies of current training programmes in the industry.

\section{Skill Gap}

Employability and development of skill are major concerns for governments and organizations in all sectors. Countries and organizations endure the high cost of either scarcities or employees deficient in the necessary skills for critical jobs. A potential global shortage of around 38 million of high skilled and 45 million of middle-skilled employees, is expected in 2020 as per McKinsey Global Institute report specified in (Dobbs et al., 2012). Therefore, the importance of developing and nurturing the required skills by preparing highly qualified calibers with qualifications that match knowledge- based and high technology labor market is unquestionable at international, national, and institutional levels.

The hospitality industry, in common with many other industries, has shown growing levels of competition and complexity over recent decades (Kandampully $\&$ Suhartanto, 2000). As people spend more time to improve their leisure lives, firms in the hospitality industry are now immersed in a highly competitive environment and need a more creative workforce to provide high quality services (Claver, Tarí, \& Pereira, 2006). Skills shortages result when there are too few people with the right set of skills to fill available positions (Retail, 2004). There have been several definitions of skills shortages or gaps in the literature. Firstly, skills shortages are defined as deficiencies within the labour pool, which create problems in recruiting new staff "caused specifically by a shortage of individuals with the required skills in the accessible labour market" (Frogner, 2002). There are also skills gaps, which are deficiencies in the skills which employees need to carry out their existing tasks (Green, 1998). Both these cases represent shortages in skills which are currently required and which may not be possessed by the existing workforce. In addition, there are skills not currently possessed by the workforce, but which an employer believes will be necessary for future if the business is to develop (Retail, 2004). These three types of skills shortages are all likely to be relevant to retail sector employment and skills issues.

The analysis of skill shortages and hard-to-fill vacancies is especially relevant in the hospitality sector (Marchante, Ortega, \& Pagán, 2006). According to Mayhew and Keep (1999), the hospitality sector is characterized by the presence of low wages, unsociable and long hours and family unfriendly shift patterns, rare incidences of equal opportunities and male domination of higher and better paid work. Also, there are a poor or non-existent career structures, informal recruitment practices, high levels of labour turnover, low presence of trade unions and difficulties in recruitment and retention (Nankervis \& Debrah, 1995). 
Although issues regarding labour market trends and labour turnover have been widely examined in the hospitality sector, the literature on skill shortages is not very abundant. Ladkin (1999) in his study argued that one of the developing key findings in the analysis of labour market trends in the hospitality industry is a shortage of labour. However, a review of the studies on the shortage of labour shows that, in general, it is difficult to design a suitable methodology to measure and analyze the data related to skill shortages.

Workplace efficiency has become a priority for employers across the globe due to the global recession and the cost cutting measures that have been employed as a result in the recent past. Completing a skills gap analysis allows organizations to stay on top of employee development, channel their resources effectively and adapt to future skills demands. Mandabach, Vanleeuwen, \& Bloomquist (2001) argued that technology is a key component of any hospitality curriculum and that the work experience portion of the curriculum is most closely correlated with increased proficiency in industry-specific software. In a study of Taiwanese hospitality industry professionals, communication skills and adaptation to environmental changes were identified as the most important competencies for career success, whereas operational knowledge and analytical techniques, problem identification, management of employees, and management of job competencies were not significantly related to career success (Lin, 2002).

Employers can employ a variety of approaches following their skills gap analysis to facilitate appropriate employee development and training plans. For example, relevant on the job training or continuing professional development to membership of professional bodies and attainment of career related qualifications could be incorporated. High-season business demands in the tourism and hospitality industry, such as time pressure, high employee turnover, rapid money turnover - especially in small businesses - and the inability to assess the benefit of training and the expertise needed to provide training, have been identified as hindering and discouraging the provision of ongoing employee training in hospitality industry (Baum, Amoah, \& Spivack, 1997; D’Annunzio-Green, Maxwell, \& Watson, 2004). Nevertheless, as per the studies by Haven-Tang \& Jones (2006) and Lucas (2004), some of these constraints in the industry are generally accepted as unavoidable and common. In addition, the tourism industry is dominated by small businesses (Baum, 1999; Lucas, 2004; Peacock \& Ladkin, 2002) with some of the owner-manager positions in these small businesses being filled by expatriates, the majority of whom lack tourism knowledge and management skills and have never undergone formal tourism training. Globally, the industry faces skills shortages in key operational, technical, and managerial areas, the extent varying between developed and developing countries. 


\section{Skill Gap Analysis}

A skill gap analysis is a methodical review of the skills possessed by individuals in a company (Clark, 2012). The procedure involved in performing skill gap analysis is to point out all the skills essential for an individual to carry out their job well (Duggan, 2013). Employers should then be able to classify the critical and noncritical skills required to attain a higher standard of work by comparing the list of required skills with the actual skills possessed by the employee (QFinance, 2009).

The results of the skill gap analysis can be used to develop training needs and type of training, support performance appraisals or justify pay reviews (Antonucci \& D’Ovidio, 2012). A skills gap analysis can really benefit by providing a critical overview of the workforce allowing managers to decide if their employees have the necessary skills to meet organizational objectives (QFinance, 2009). If employees do not possess the required skills, an organization can use the skills gap analysis to prioritize the type of training so that they are tailored to specific job roles, as opposed to generic training days that are not suitable for all the individuals participating. Research by Mudor (2011) indicates that providing appropriate opportunities for training that link business and individual skills needs may influence workers to stay with an employer for longer, maximizing the benefits of increased employee productivity due to a higher level of skills when considered against the original cost of training. Further long-term savings are made as employees feel valued and increasingly willing to remain with their employer, reducing the costs associated with staff turnover (Skills, 2012). It is further required to identify staff members possessing knowledge in a particular area and workforce lacking certain skills facilitating the mentoring process within teams, as well (QFinance, 2009). Skill gap analysis can also support recruitment practices as employers can select candidates with preferred skills required by a particular department. Traditionally, a skill gap analysis is undertaken using paper-based assessments and supporting interviews; however, technological advancements, such as skill management software, are allowing large companies to administer a skill gap analysis without using a significant proportion of human resources (Antonucci \& D’Ovidio, 2012).

If employees are more willing to remain with a company and progress their careers, then they become part of the organization's talent pipeline facilitating effective succession planning and contributing to the success of an organization's overall talent management strategy.

\section{Objectives of the Study}

The study investigates the trends, constraints, and opportunities faced by the hospitality sector in selected districts of the three southern states of India, namely 
Karnataka, Kerala, and Tamil Nadu. The main purpose of the study is to find out the intensity of labor and skill gap in the hospitality sector.

\section{Methodology}

The study investigates the intensity of labour and skill gap in the hospitality sector in selected districts of the three southern states of South India, namely Karnataka, Kerala, and Tamil Nadu. The study is an empirical one, using both primary and secondary data. The analysis of secondary data involved a comprehensive literature review of published and semi-published sources, including, journals, magazines and reports of various committees, and data published by NABARD and other relevant agencies in regard to the rural service sector at the macro level. The micro level empirical part of the research study was based on a field survey confined to the hospitality sector in Karnataka, Kerala, and Tamil Nadu. The study was carried out with a structured questionnaire applied to hospitality service providers of undivided Dakshina Kannada and Uttara Kannada district of Karnataka state; Wayanad and Alappuzha district of Kerala state; Madurai and Kanyakumari district of Tamil Nadu.

For the purpose of the study, the sample consisted of 50 respondents each from each of the selected districts. The sample size of 50 was decided based on the time and cost involved. Hence, 306 hospitality service providers were interviewed. The purpose of the exercise is to have a representative sampling. Thus, the list of the rural service sector would be collected from the ZillaPanchayat / municipality of the selected districts. However, based on the field conditions, the study adopted purposive/snowball sampling. A cross-sectional analysis of the field data, state-wise, is carried out to draw inferences relating to the objectives set in the study, with particular emphasis on employment generation, labour intensity, economic - empowerment, and the role played by various agencies in supporting the efforts of these service providers. The sub-sectors of the hospitality sector include; 1. Boarding and lodging, 2. Restaurants/Food and Beverage, 3. Travel agencies, 4. Tour guides/information providers, 5. Activities such as scuba diving, boat house, etc., and 6 . Home stay.

\section{Data Analysis}

This research is designed as a cross-sectional data analysis to examine the regional differences and impediments in the growth of the hospitality sector. In order to carry out the cross-sectional analysis, the field level survey data was collected from a sample of 306 hospitality service providers in the selected districts. 


\section{Profile of the Respondents}

Table 1 shows the industry-wise and location-wise breakup of the surveyed firms in all the six districts, respectively. Overall, lodges and restaurants (food and beverage) are high in number compared to all other hospitality service providers in each of the district studied. Further, the number of house boats were more in the Alappuzha district, when compared to other hospitality service providers in that region, and the proportion of home stays were more in the Wayanad district of Kerala state. Recreation activities were seen in the Uttara Kannada and Dakshina Kannada district. To elaborate, adventure activities were observed in Dandeli taluk of Uttara Kannada district and water sports activities were observed in two firms in the undivided Dakshina Kannada district.

Table 1

District - Wise Classification of Respondents based on the Service Provided

\begin{tabular}{|c|c|c|c|c|c|c|c|}
\hline \multirow[b]{2}{*}{ Service } & \multicolumn{2}{|c|}{ Kerala } & \multicolumn{2}{|c|}{ Tamil Nadu } & \multicolumn{2}{|c|}{ Karnataka } & \multirow[b]{2}{*}{ Total } \\
\hline & Alappuzha & Wayanad & Kanyakumari & Madurai & $\begin{array}{l}\text { Dakshina } \\
\text { Kannada }\end{array}$ & $\begin{array}{l}\text { Uttara } \\
\text { Kannada }\end{array}$ & \\
\hline Adventure & 0 & 0 & 0 & 0 & 2 & 8 & 10 \\
\hline $\begin{array}{l}\text { Food and } \\
\text { Beverage }\end{array}$ & 5 & 15 & 13 & 9 & 15 & 15 & 72 \\
\hline $\begin{array}{l}\text { Home } \\
\text { Stay }\end{array}$ & 7 & 9 & 0 & 1 & 0 & 7 & 24 \\
\hline $\begin{array}{l}\text { House } \\
\text { Boat }\end{array}$ & 34 & 0 & 0 & 0 & 0 & - & 34 \\
\hline Lodging & 5 & 19 & 32 & 39 & 29 & 23 & 147 \\
\hline $\begin{array}{l}\text { Resort } \\
\text { Tour }\end{array}$ & 0 & 4 & 0 & 0 & 0 & 2 & 6 \\
\hline $\begin{array}{l}\text { Operators } \\
\text { /Travel } \\
\text { Agency }\end{array}$ & 0 & 3 & 5 & 1 & 4 & - & 13 \\
\hline Total & 51 & $\mathbf{5 0}$ & 50 & $\mathbf{5 0}$ & 50 & 55 & 306 \\
\hline
\end{tabular}

\section{Capital Usage}

The sample size is well spread across the firms with the different capital requirement. A large number of firms surveyed had an investment of Rs. 10 lakhs to Rs. 50 lakhs. This could be observed in Table 2 . 
Table 2

District - Wise Classification of Respondents, based on the Capital Investment

\begin{tabular}{|c|c|c|c|c|c|c|c|c|}
\hline \multirow{2}{*}{$\begin{array}{l}\text { Capital } \\
\text { Invested }\end{array}$} & \multirow{2}{*}{ Alappuzha } & \multirow{2}{*}{ Wayanad } & \multirow{2}{*}{ Kanyakumari } & \multirow{2}{*}{ Madurai } & \multirow{2}{*}{$\begin{array}{l}\text { Dakshina } \\
\text { Kannada }\end{array}$} & \multirow{2}{*}{$\begin{array}{l}\text { Uttara } \\
\text { Kannada }\end{array}$} & \multicolumn{2}{|c|}{ Total } \\
\hline & & & & & & & Number & Percent \\
\hline $\begin{array}{l}\text { Below } \\
100000\end{array}$ & 0 & 1 & 0 & 2 & 1 & 4 & 8 & 2.6 \\
\hline $\begin{array}{l}100000- \\
1000000\end{array}$ & 8 & 7 & 14 & 11 & 10 & 19 & 69 & 22.5 \\
\hline $\begin{array}{l}1000000- \\
2500000\end{array}$ & 8 & 15 & 17 & 18 & 20 & 27 & 105 & 34.3 \\
\hline $\begin{array}{l}2500000- \\
5000000\end{array}$ & 17 & 13 & 10 & 10 & 12 & 4 & 66 & 21.7 \\
\hline $\begin{array}{l}5000000- \\
7500000\end{array}$ & 8 & 5 & 6 & 7 & 2 & 1 & 29 & 9.5 \\
\hline $\begin{array}{l}7500000- \\
1 \text { crore }\end{array}$ & 9 & 1 & 2 & 2 & 1 & 0 & 15 & 4.9 \\
\hline $\begin{array}{l}\text { Above } 1 \\
\text { crore }\end{array}$ & 1 & 8 & 1 & & 4 & 0 & 14 & 4.6 \\
\hline Total & 51 & 50 & 50 & 50 & 50 & 55 & 306 & 100 \\
\hline
\end{tabular}

\section{Labour Intensity}

Table 3 depicts the district-wise data on a total number of the workforce employed and the number of vacant positions. The trend in the number of the workforce employed is almost similar (ranging from 16 to 20\%) in almost all the districts surveyed, except in Alappuzha, where it is $10.84 \%$.

Table 3

District-Wise Classification of Workforce Employed and Vacant Positions in the Hospitality Sector

\begin{tabular}{|c|c|c|c|c|c|c|c|c|c|}
\hline \multirow{3}{*}{ District } & \multicolumn{6}{|c|}{ Employed } & \multicolumn{3}{|c|}{ Vacant Position } \\
\hline & \multicolumn{2}{|c|}{ Male } & \multicolumn{2}{|c|}{ Female } & \multicolumn{2}{|c|}{ Total } & \multirow{2}{*}{ Male } & \multirow{2}{*}{ Female } & \multirow{2}{*}{ Total } \\
\hline & No. & Percent & No. & Percent & No. & Percent & & & \\
\hline Madurai & 392 & 14.51 & 87 & 3.22 & 479 & 17.73 & 145 & 64 & 209 \\
\hline Kanyakumari & 390 & 14.43 & 79 & 2.92 & 469 & 17.36 & 82 & 20 & 102 \\
\hline Alappuzha & 273 & 10.10 & 20 & 0.74 & 293 & 10.84 & 23 & 2 & 25 \\
\hline Wayanad & 386 & 14.29 & 96 & 3.55 & 482 & 17.84 & 312 & 97 & 409 \\
\hline $\begin{array}{l}\text { Uttara } \\
\text { Kannada }\end{array}$ & 342 & 12.66 & 108 & 4.00 & 450 & 16.65 & 41 & 7 & 48 \\
\hline $\begin{array}{l}\text { Dakshina } \\
\text { Kannada }\end{array}$ & 437 & 16.17 & 92 & 3.40 & 529 & 19.58 & 4 & 3 & 7 \\
\hline Total & 2220 & 82.16 & 482 & 17.84 & 2702 & 100.00 & 607 & 193 & 800 \\
\hline
\end{tabular}

It could be observed here that women constitute hardly $17.84 \%$ in the total of 306 firms surveyed across the districts. Barriers to women entering employment in the sector were highlighted consistently, with the lowest percentage of female staff recruited across the sample surveyed. The low numbers of female staff were attributed to social stigma and misconceptions which surround the tourism 
and hospitality industry. Women in the sector are mainly employed in low-skilled jobs, especially as cleaning staff. Further, 800 vacant positions exist in the firms surveyed. Generally, owners were men. Among the 306 firms, two hotels only had women owners.

According to Table 4, the mean number of vacancies in the last 12 months in the 306 firms surveyed was 3.85. From the total number of firms, $19.48 \%$ reported vacancy in the last 12 months, and the percentage of such vacancies over the total number of employees was $22.84 \%$. The mean number of hard-to-fill vacancies in the last 12 months was 3.67. The percentage of firms having at least one difficultto-fill vacancy was $29.09 \%$. The hard-to-fill vacancies as a percentage of the total number of employees and the total number of vacancies were $13.85 \%$ and $39.01 \%$, respectively.

Table 4

Incidence of Total Vacancies and Hard-to-Fill Vacancies

\begin{tabular}{llr}
\hline \multirow{2}{*}{ Total vacancies } & Mean number of vacancies & 3.85 \\
& \% of firms reporting vacancies & 19.48 \\
& Vacancies as \% of employment & 22.84 \\
\hline \multirow{3}{*}{ Hard-to-fill vacancies } & Mean number of hard-to-fill vacancies & 3.67 \\
& \% of firms reporting hard-to-fill vacancies & 29.09 \\
& Hard-to-fill vacancies as \% of employment & 13.85 \\
& Hard-to-fill vacancies as \% of vacancies & 39.01 \\
\hline Note. Source: Field Survey Data. & &
\end{tabular}

Note. Source: Field Survey Data.

Around $19.5 \%$ of the firms surveyed reported vacancies in the workforce and around $29 \%$ stated that there are hard-to-fill vacancies, also. Hard-to-fill vacancies generally exist in the area of cleaning staff and skilled chefs. It is hard to find cleaning staff, particularly for the food and beverage firms. Further, it is difficult to find a skilled chef who can cook all kinds of dishes, other than the local dishes. Such positions are often filled with applicants who cannot find a job elsewhere. It is difficult to recruit members of staff with the appropriate skills, but also with a sense of flexibility, willingness, and presentation. Licensed $\operatorname{srank}^{1}$ and motor mechanics are further hard-to-fill vacancies in house boats, as reported by the respondents. Based on the survey, it was found that the major deterrent in hiring more people are long working hours, migration of work force to well-developed cities in search of a better job, and difficult-to-find trustworthy employees. It was also observed that some workers find jobs in the hospitality sector as an alternate source of employment during the off season in agriculture.

1 Shrank is the designation of the drivers who operate house boats; this is the commonly used term in the Kerala State of India. 


\section{Demographics}

Figure 1 illustrates the existing qualification levels obtained from the supplied workforce information.

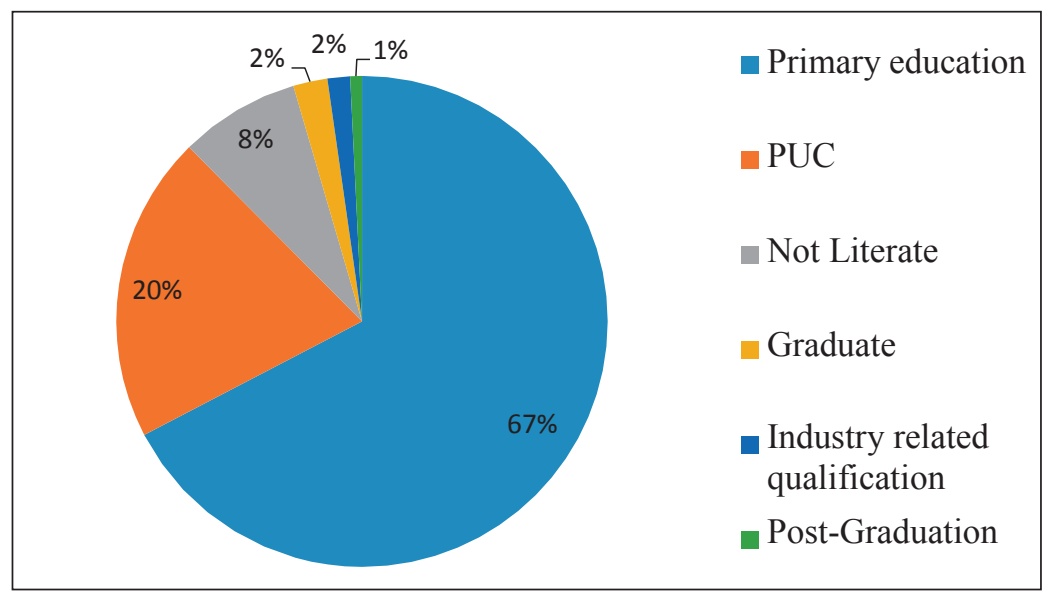

Note. Source: Field Survey Data.

Figure. 1. Education level of respondents' workforce.

$67.36 \%$ of the workforce employed had primary education, while around $8 \%$ had no literacy. $1 \%$ of the respondents were post-graduates, and $1.48 \%$ of the sample had some industry-related qualification. It was also observed during the survey that, once the workforce gains some amount of experience, they tend to switch over to better hotels/ restaurants for a higher pay. This was a common problem in most of the sample surveyed. Such labour turnover was more in semiskilled jobs.

Of the 306 firms surveyed, 209 (67.8\%) hired workers based on prior training or knowledge. They had the basic knowledge as to what is the expected work to be done. All the house boat owners hired workers based on prior knowledge of the work. It is also evident from the below table that more than 50 percent of the hospitality service providers employed the workers based on prior training or prior knowledge about the basic work they are expected to do. This can be observed in Figure 2. 


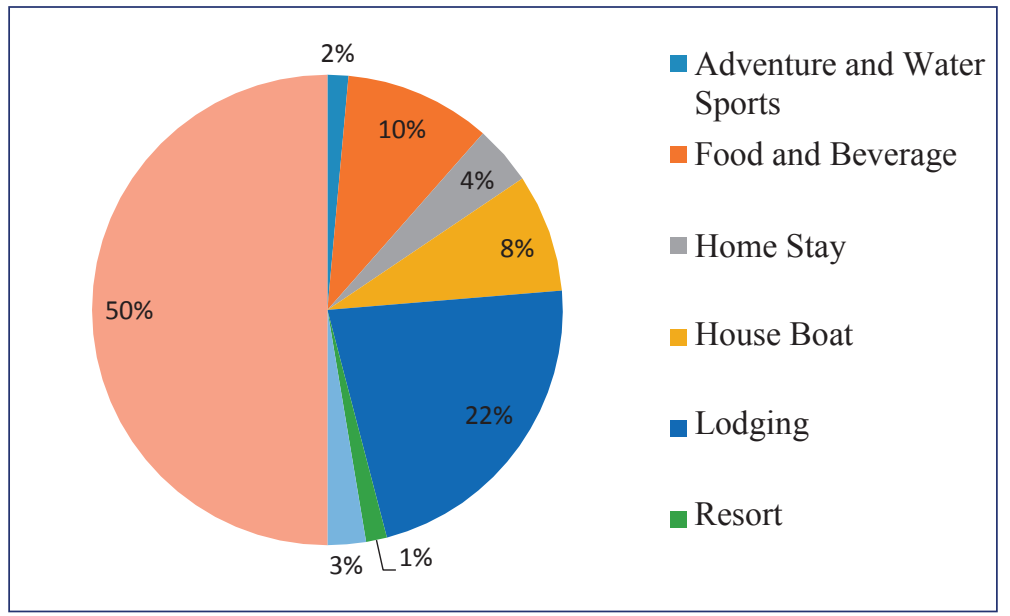

Note. Source: Field Survey Data.

Figure. 2. Classification of service providers based on worker's prior training.

Further, an attempt was made to know the categories where a shortage of labor was found among the hospitality service providers. Figure 3 summarizes the shortage of labor in the respective firms. Based on the response of the various service providers, it was observed that house boat and food and beverage firms had a major shortage in skilled staff. Skilled staff in food and beverage firms comprises of supervisors and chef workers, and sranks were the skilled workers in house boats. The industry had limited number of licensed sranks.

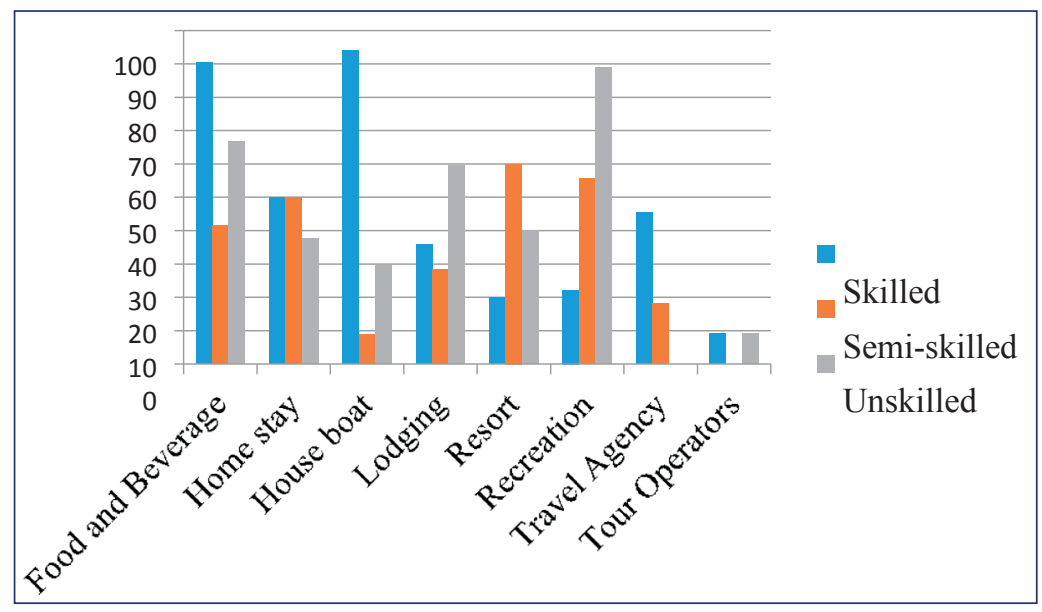

Note. Source: Field Survey Data.

Figure 3. Shortage of labor (\%). 


\section{Skill Gap}

An attempt was made to identify the skill gaps among the workers in the surveyed units. The opinion of the management was taken for this purpose. Figures 4 through 10 narrate the skill gap among the operational and supervisory level employees' observed skills. Overall, improper oral communication was observed as a major skill gap in almost all the sub-sectors, irrespective of the level of occupation. With respect to the home stays, lack of technology related skill in terms of handling emails and websites were observed to be the major skill gap.

In addition, food and beverage firms also had an issue of cuisine with improper knowledge on various dishes other than the local ones. The surveyed districts are tourist spots having tourists from places all over the country. Hence, language and communication of the front-end servicing staff play a pivotal role. It is also worth noting that lifesaving rescue skills of the guest are an important skill which is indeed lacking among all the employees in the house boats surveyed.

To add, the drivers and the front-end staff of the travel agencies lack communication skills. Most of them had limited adherence to driving rules and regulations and also had inadequate knowledge of safety norms.

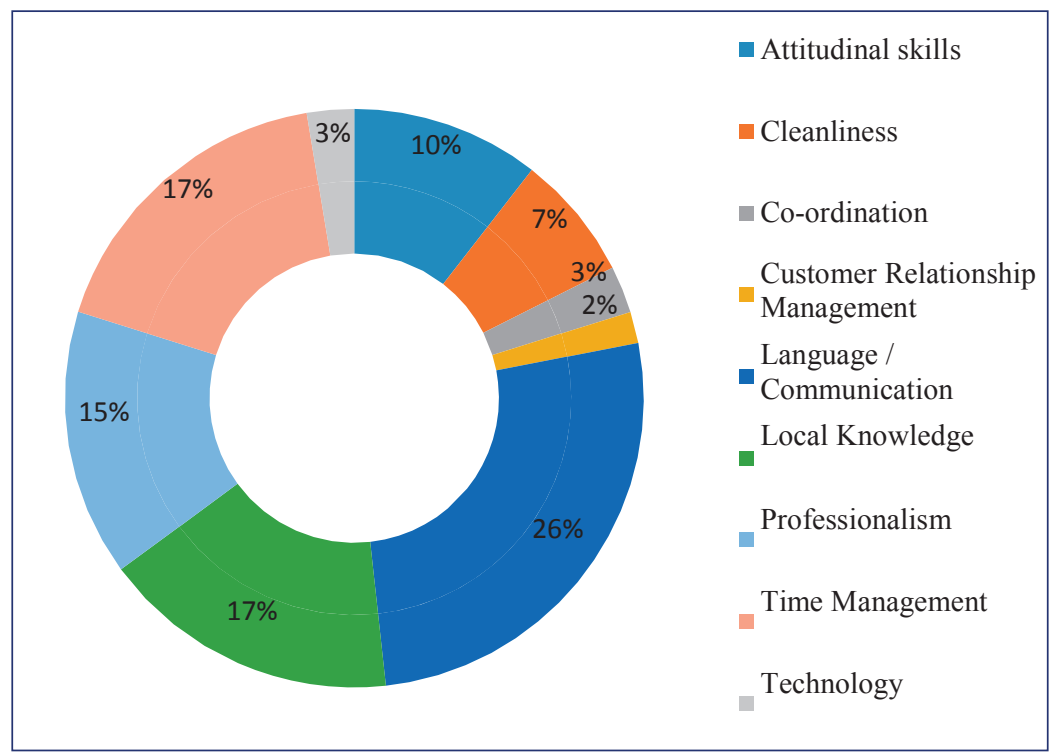

Note. Source: Field Survey Data.

Figure 4. Skill gap reported for the operational level in lodging. 


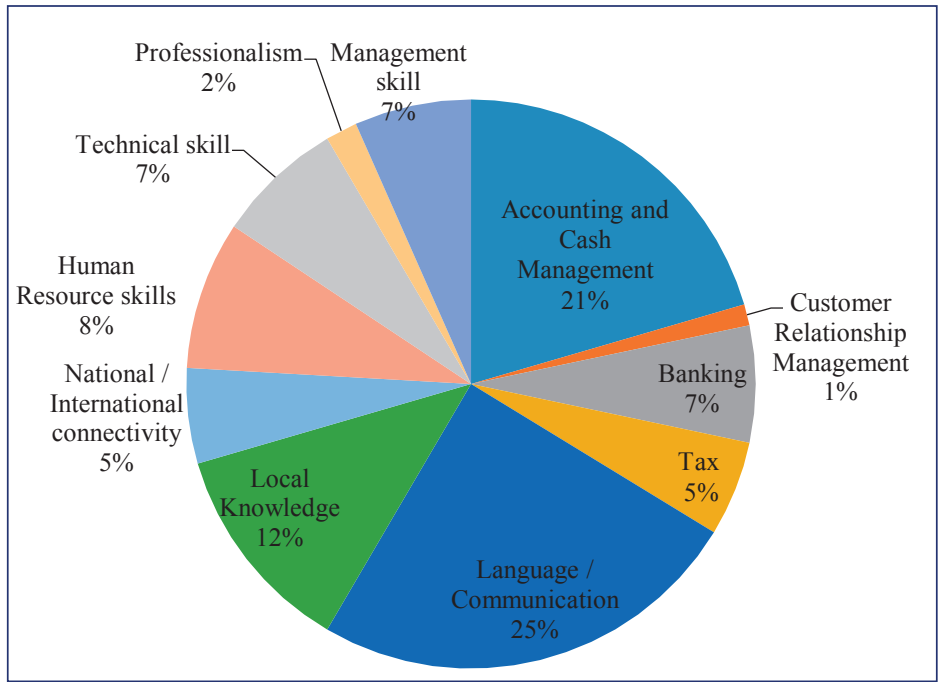

Note. Source: Field Survey Data.

Figure 5. Skill gap reported for the supervisory level in lodging.

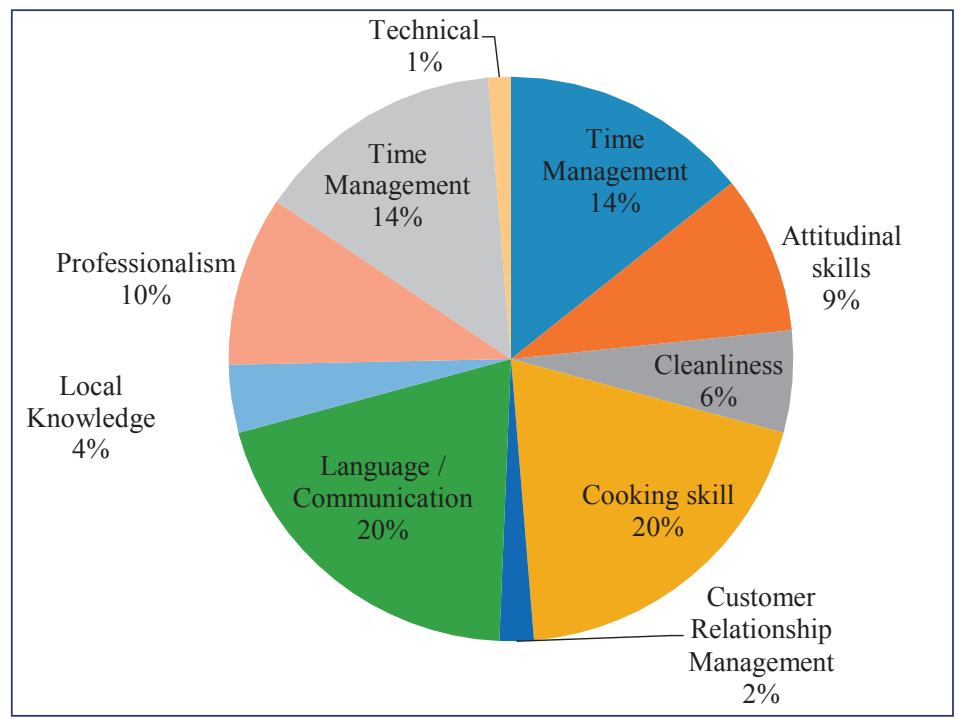

Note. Source: Field Survey Data.

Figure 6. Skill gap reported for the operational level in the food and beverage sector. 


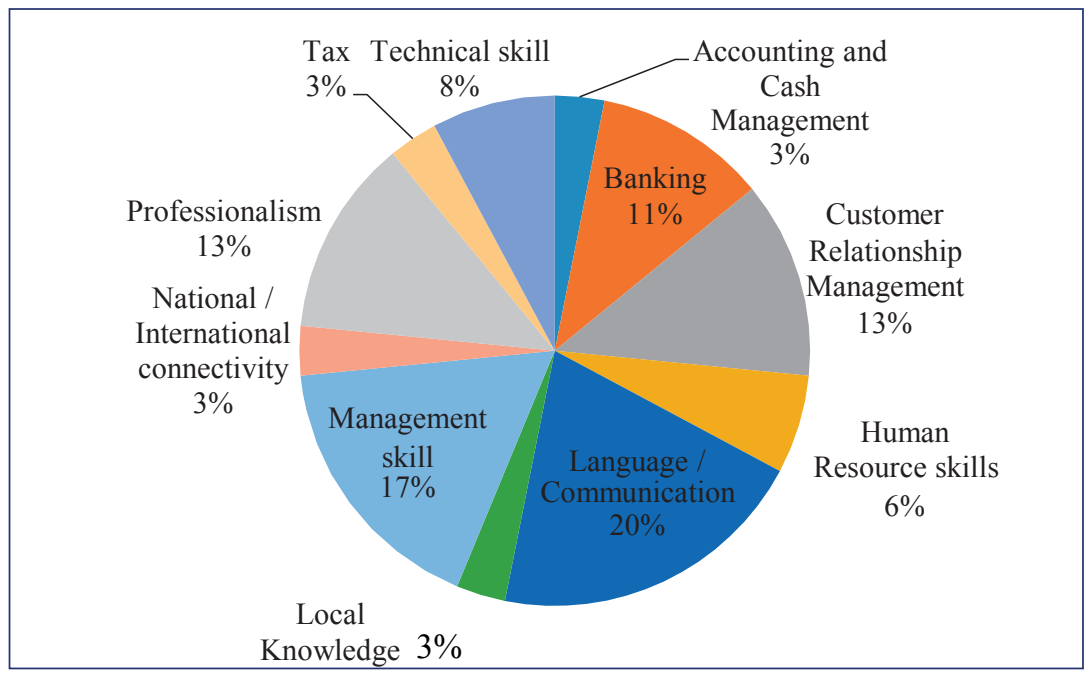

Note. Source: Field Survey Data.

Figure 7. Skill gap reported for the supervisory level in the food and beverage sector.

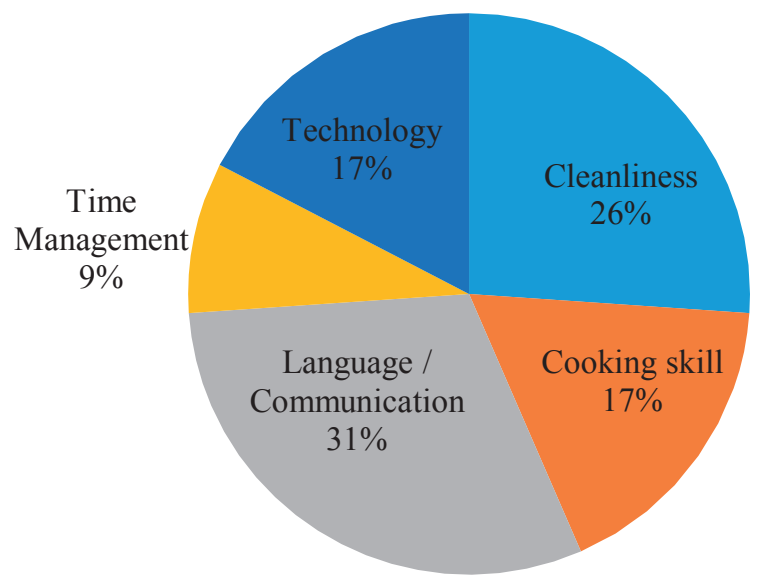

Note. Source: Field Survey Data.

Figure 8. Skill gap reported for the operational level in home stays. 


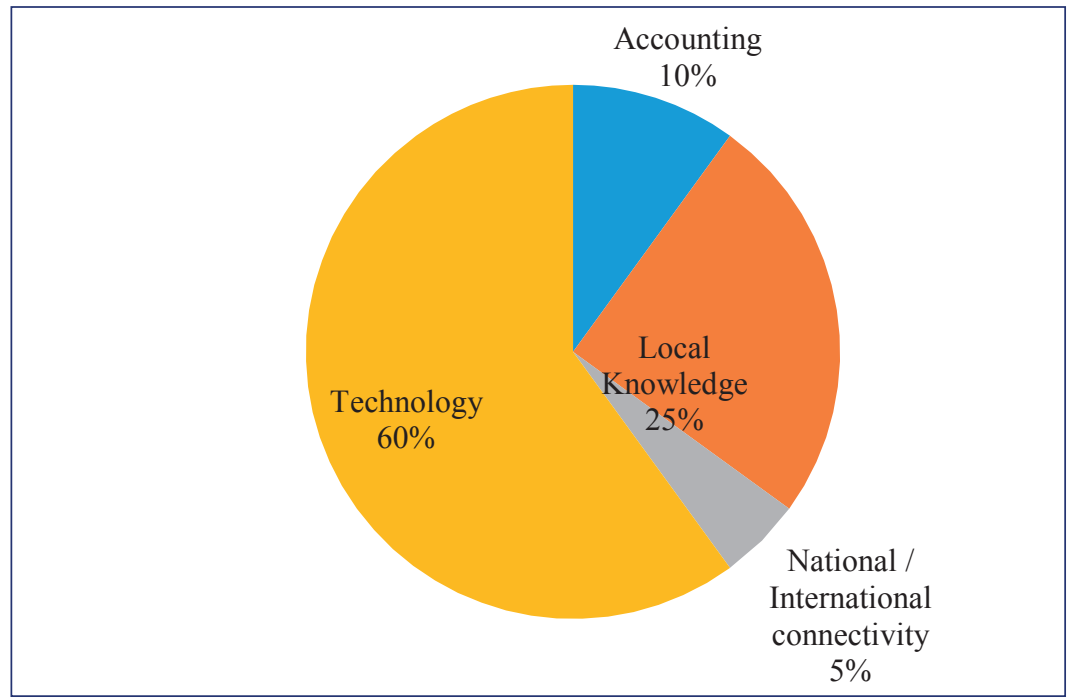

Note. Source: Field Survey Data.

Figure 9. Skill gap reported for the supervisory level in home stays.

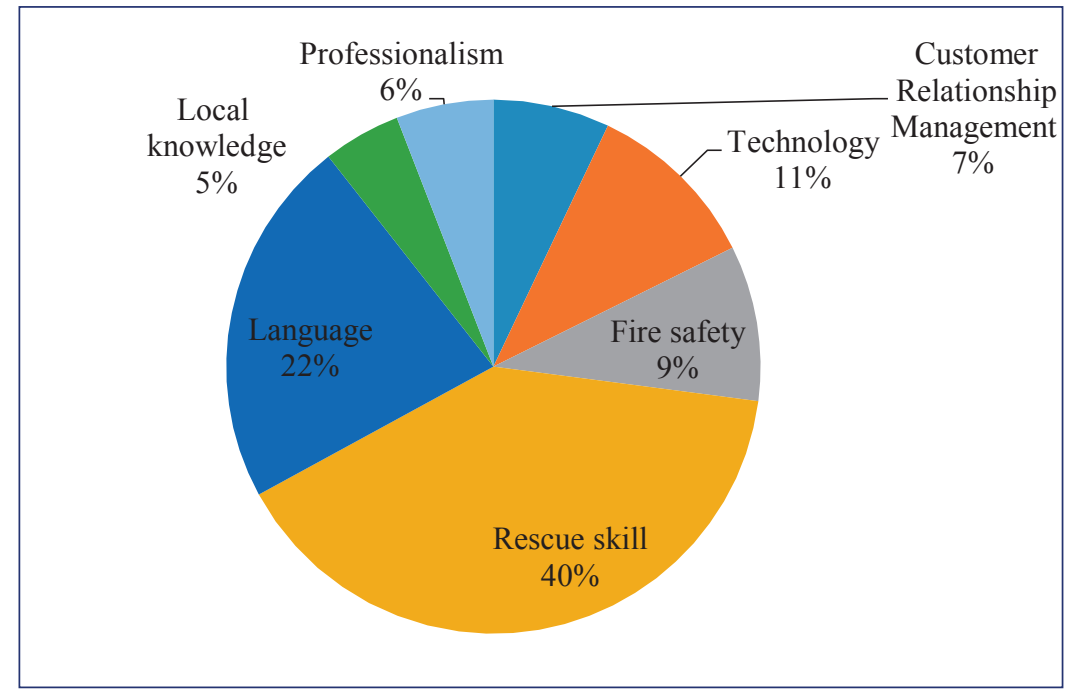

Note. Source: Field Survey Data.

Figure 10. Skill gap reported for the operational level in house boats. 
An attempt was made further to analyze what are the factors that can be used to manage the skill gap. A chi-square test was conducted in this regard. As far as managing the skill gaps are concerned, salary is a highly important factor. Beside the industry level effort $(21 \%)$, the inhouse training also helps to reduce the skill gap. During the discussion with the entrepreneurs, it was found that most of the labours would not possess any skills required for the job. It is due to the fact that the in-house training programs conducted over a period of time makes them possess the skills required. Therefore, in-house training plays an important role in bridging the skill gap. Further, based on Table 5, it is evident that the chi-square significance value is 0.000 , which is less than 0.05 .

Table 5

Chi-Square Tests

\begin{tabular}{lccc}
\hline & Value & Df & Asymp. Sig. (2-sided) \\
\hline Pearson Chi-Square & $983.286(\mathrm{a})$ & 28 & 0.000 \\
Likelihood Ratio & 1061.770 & 28 & 0.000 \\
Fisher's Exact Test & .(b) & & \\
$\mathrm{N}$ of Valid Cases & 2440 & \\
Note. & \\
a. 0 cells $(.0 \%)$ have expected count less than 5. The minimum expected count is 52.88. \\
b. Cannot be computed because there is insufficient memory.
\end{tabular}

\section{OLS Regression Analysis}

An attempt is made in this section to determine the relative importance of various determinant factors for growth of the hospitality sector by using OLS regression analysis. The model given below is used to test the articulation of skill gap, the influence of infrastructure development and growth in wages on the sales growth while controlling investment, total employees, and age of the service providers. The regression equation is:

$\mathrm{YGS}=\alpha+\beta 1 \mathrm{SGAP}+\beta 2(\mathrm{INF})+\beta 3 \mathrm{GWAG}+\beta 4 \mathrm{AGE}+\beta 5 \mathrm{DER}+\beta 4 \mathrm{INVST}+\beta 4 \mathrm{EMP}$

where GS is growth in sales; SGAP is an articulation of skill gap; INF is an improvement in infrastructure; GWAG is growth rate in wages; AGE is the age of the firm; DER is debt equity ratio; INVST is investment; and EMP is the number of employees employed.

Articulation of skill gap was a dummy variable coded as 1 if the firm could articulate the skill gap and 0 , otherwise. Improvement in infrastructure is computed as the aggregate of responses given by the firms with respect to the improvement required in infrastructure. A Likert scale was used to measure the improvement required, with 1 representing high improvement required and 5 representing least improvement required. In other words, the higher the number, 
the lesser improvement required and vice versa. Growth in wages is the percentage growth rate increase in the wages over the last three years. Age was measured as the number of years the business has completed. Debt equity ratio is computed as the proportion of debt to total equity. Investment is a total investment made by the firm in rupees. Total employees are the absolute value derived, i.e., the total male and female workers who are already employed in the firms.

Further, debt equity ratios, the age of the firm, investment, infrastructure, total employees and growth in wages were standardized due to the different measurement scales. Table 6 summarizes the results of the OLS regression for the sample surveyed. The result suggests that articulation of skill gap is highly significant. It means the growth in the top line is largely influenced by the articulation of skill gap. The positive relationship between the growth and skill gap articulation could be observed from the above data. The firms who could articulate the skill gap were able to achieve better growth compared to that of firms unable to articulate. Therefore, it is imperative that the articulation of skill gap is one of the important skills to be focused on. The fundamental reason is that if the management could articulate the skill gap, they could also assess the type of training to be provided and thus in turn efficiency would be improved and this could be reflected in sales.

Table 6

\section{OLS Regression Summary for the Sample Surveyed}

\begin{tabular}{|c|c|c|c|c|c|}
\hline Particulars & Coefficient & Std. Error & t-ratio & p-value & Sig. \\
\hline Const & -0.380 & 0.088 & -4.390 & 0.00002 & $* * *$ \\
\hline Skill Gap Articulation & 0.610 & 0.112 & 5.450 & $<0.00001$ & $* * *$ \\
\hline Improvement in Infrastructure & -0.042 & 0.055 & -0.780 & 0.43867 & \\
\hline Growth in Wages & 0.096 & 0.052 & 1.845 & 0.06597 & $*$ \\
\hline Age & -0.170 & 0.055 & -3.190 & 0.00156 & $* * *$ \\
\hline Debt Equity Ratio & -0.110 & 0.053 & -2.140 & 0.03310 & ** \\
\hline Investment & 0.214 & 0.058 & 3.702 & 0.00025 & $* * *$ \\
\hline Total Employees & -0.158 & 0.058 & -2.740 & 0.00654 & $* * *$ \\
\hline \multicolumn{6}{|l|}{$F(7,300): 9.835$} \\
\hline Adjusted R-squared: 0.16 & & & & & \\
\hline
\end{tabular}

Improvement in infrastructure negatively influenced the growth. However, the relationship is not statistically significant. It could be understood that tourists visit the spots irrespective of the infrastructure development. Irrespective of the minimal infrastructure development taken place in this region, there is a spurt in tourism. Counter intuitively the growth in wages did not impact the growth negatively. We see the positive relationship between wage rate growth and growth in sales. At least empirically we do not find that the increase in the wage rate is hindering the growth. It is also important to note that with the increase in the inflation in the economy we see wage rate going up and correspondingly the prices also shoot up. 


\section{Discussion}

\section{Labour Intensity and Skill Gap}

Currently, the hospitality sector in India is viewed as a second/ alternative choice due to limited opportunities for progression, and the seasonal approach to work. This is partly because it is characterised by large numbers of low skilled opportunities. As such, developing defined opportunities for a career progression is an important factor in encouraging people to view hospitality as a viable career option. This includes focusing on carving out clear career paths for staff entering the organisation at the entry level. This is important because one of the reasons for the high attrition rates across the sector is the fact that barriers to entry are low. Individuals can enter into the industry relatively easily but also often for a specific short-term need creating a transient workforce. It is, therefore, important for organisations to be able to integrate progression into training and employment.

Vacancy statistics: Vacancy statistics can be an indicator of skill shortage and labour demand. Strong growth in the number of vacancies may indicate demand for skills in a particular industry and large numbers of unfilled vacancies can point to a skill shortage. As much as $22.84 \%$ of the total employment were found to be vacant in the sample surveyed.

Limited availability of local labour for minimally skilled jobs: A major limitation faced by the hospitality sector is the local labour constraints. The firms are increasingly relying on migrant labour from other states who are more willing to take up such jobs since the wages are attractive compared to similar jobs in their home states.

\section{Skills that Need Improvement}

As much as $60.3 \%$ of the employers report the existence of skills gaps, and many say that their staff do not have the necessary customer service and management and communication skills. In addition, these workers $(98 \%)$ lack industry-related qualification. The present skills which they possess are derived from their past services / practices in the industry.

Among the array of possibilities for skills improvement (as suggested by the survey's questionnaires), communication skill was considered very much necessary by more than $50 \%$ of the employers. Job-specific tasks, management skills, and accounting skills were considered necessary and was lacking among the staff of lodging and food and beverage firms. To substantiate with an example, based on the survey findings, the majority of house boat workers lack fire safety skills, rescue skills, and communication skills. 
The present fear with the management is that if their employees are trained, they will shift to better jobs, which are again a problem for the management. Based on the field survey and observations, an attempt was made in Table 7 to summarize, overall, the list of skills that are needed to be improved among the hospitality staff.

Table 7

The Skills That Need Improvement

\begin{tabular}{ll}
\hline Level & Skill Gap \\
\hline $\begin{array}{l}\text { Restaurants and Hotels/Resorts } \\
- \text { Management and Proprietors }\end{array}$ & Limited Management Skills \\
Limited Accounting, Tax, Banking, and Business Knowledge \\
Limited Computer Literacy
\end{tabular}

\section{Conclusions}

The study primarily analyses the human resource intensity and skill gap in the hospitality industry and tries to bridge the gap to attain self-sufficiency. The Central Government has initiated several innovative initiatives to rejuvenate the rich cultural heritage that India possesses. India has vast scope to encash this opportunity. To facilitate this programme, the Government has set up various training and educational programs to create awareness so that people tap the enormous potential that India has.

The Ministry of Tourism has also formulated schemes for Financial Assistance to IHMs, FCIs, IITTM, ITIs, Polytechnics, Institutes, Vocational Schools, and so on, for the setting up and upgradation of Institutes of Hotel Management \& Catering Technology \& Applied Nutrition (IHMs), FoodCraft Institutes (FCIs) in the country. The Government/Ministry of Tourism has taken several initiatives to build skills in the tourism sector. 
India has the potential to become the number one tourist destination in the AsiaPacific region, with the demand growing at $10.1 \%$ per annum as per the data released by WTTC. Further, India has the second largest population in the world, estimated at 1.4 billion. By 2016, its population was expected to be bigger than the populations of the US, Europe, Russia, Australia, Japan, and Canada combined. The global population is evolving, and the tourists' pockets of disposable income available for travel are shifting. Affluent baby boomers in the western world are moving into retirement, living longer, and becoming more interested in travel experiences. The middle classes in emerging markets are expanding. Most of the new entrants will come from China and India. Care should be taken that products and services are targeted to the attitude of 'agelessness' and interest in experimental travel shown by the boomers, appealing to the thin sense of adventure, independent spirit and desire to explore off the beaten tourist track.

The value of the brand to the consumers, the growth in emerging markets, the importance of consumers facing technology and the sourcing development and retention of human capital will be the key to sustained growth. This paper aimed to explore in detail these key trends, which impact both the hospitality industry and the related sectors, which makes the travel experience viable.

The findings of the present study are based on the sample of hospitality firms in South India. Further research may compare the skill gaps in hospitality sectors in other regions, such as North India, Eastern India, and the Western part of India.

\section{References}

Antonucci, L., \& D’Ovidio, F. D. (2012). An Informative System Based on the Skill Gap Analysis to Planning Training Courses. Applied Mathematics, 3(11), 1619-1626. Athey, R. (2004). It's 2008: Do You Know Where Your Talent Is? New York. Bailey, P. H. (1997). Finding your way around qualitative methods in nursing research. Journal of Advanced Nursing, 25(1), 18-22.

Baum, T. (1999). Human resource management in tourism small business sector: Policy dimension. In HRM in tourism and hospitality: International perspectives on small to medium sized enterprises (pp. 3-16). New York, NY: Cassell.

Baum, T., Amoah, V., \& Spivack, S. (1997). Policy dimensions of human resource management in the tourism and hospitality industries. International Journal of Contemporary Hospitality Management, 9(5/6), 221-229.

Bennett, J. (2010). Vibrant Matter: A Political Ecology of Things. Durham, NC: Duke University Press.

Bennett, N., Dunne, E., \& Carre, C. (2000). Skills development in higher education and employment. United Kingdom: SHRE and Open University Press.

Blake, A., Sinclair, M. T., \& Soria, J. A. C. (2006). Tourism productivity: Evidence from the United Kingdom. Annals of Tourism Research, 33(4), 1099-1120.

Bradley, H., Erickson, M., Stephenson, C., \& Williams, S. (2004). Myths at Work. 
Cambridge: Polity.

Chathoth, P. K., \& Olsen, M. D. (2002). Organisational leadership and strategy in the hospitality industry. Journal of Services Research, 2(1), 5-29.

Clark, W. (2012). Definition of skills gap analysis. Retrieved from http://www.ehow. co.uk/facts_6788842_definition-skills-gap-analysis.html

Claver, E., Tarí, J. J., \& Pereira, J. (2006). Does quality impact on hotel performance? International Journal of Contemporary Hospitality Management, 18(4), 350-358.

Coy, J. (2006). Shrinking Labor Force is Top Challenge for Global Hospitality, Tourism \& Service Industries. Atlanta.

D’Annunzio-Green, N., Maxwell, G. A., \& Watson, S. (2004). Human Resource Management: International Perspectives in Hospitality and Tourism. London: Cengage Learning EMEA.

Diplari, A., \& Dimou, I. (2010). Public Tourism Education and Training in Greece. Industry and Higher Education, 24(2), 115-120.

Dobbs, R., Remes, J., Manyika, J., Roxburgh, C., Smit, S., \& Schaer, F. (2012). Urban world: Cities and the rise of the consuming class. Washington DC.

Duggan, T. (2013, January 31). How to develop a skills gap analysis. Houston Chronicle. Texas. Ecotec. (2001). Sector Skills Study: food and drink manufacturing. Birmingham.

Education, C. for T. M. (CTM) S. C. C. (2000). Best practice in co-operative education. Durban.

Erasmus, J., \& Breier, M. (2009). Skills Shortages in South Africa Case Studies of Key Professions. (J. Breier \& E. Mignonne, Eds.). Cape Town: HSRC Press.

Frogner, M. L. (2002). Skills shortages. Labour Market trends (1st ed.). London, UK: Palgrave Macmillan. Gabriel, Y. (1988). Working lives in catering. London, UK: Routledge \& Kegan Paul.

Georgiadis, A., \& Pitelis, C. N. (2008). HRM practices and knowledge processes outcomes: empirical evidence from a quasi-experiment on UK SMEs in the tourism hospitality and leisure sector. London, UK: Centre for Economic Performance, London School of Economics and Political Science.

Green, F. (1998). The Value of Skills (No. 9819). Canterbury.

Griesel, H., \& Parker, B. (2009). A baseline study on South African graduates from the perspective of employers. Pretoria: Higher Education South Africa.

Guerrier, Y., \& Deery, M. (1998). Research in hospitality human resource management and organizational behaviour. International Journal of Hospitality Management, 17(2), 145-160.

Haven-Tang, C., \& Jones, E. (2006). Learning Provision, the Labour Market and Skills Needs of the Tourism and Related Sectors in Wales. Journal of Human Resources in Hospitality \& Tourism, 5(2), 13-35.

Hjalager, A. M. (2003). Global tourism careers: Opportunities and dilemmas facing higher education in tourism. Journal of Hospitality, Leisure, Sports and Tourism Education, 2(2), 26-38.

Hoddinott, S. (2004). The assessment of workers basic skills: A critique based on evidence from the United States, Canada and England. In H. Rainbird, A. Fuller, \& A. Munro (Eds.), Workplace learning in context (pp. 89-106). London, UK: Routledge. 
Jameson, S. M., \& Holden, R. (2000). "Graduateness" - who cares? Graduate identity in small hospitality firms. Education + Training, 42(4/5), 264-271.

Kandampully, J., \& Suhartanto, D. (2000). Customer loyalty in the hotel industry: the role of customer satisfaction and image. International Journal of Contemporary Hospitality Management, 12(6), 346-351.

Ladkin, A. (1999). Hotel general managers: A review of prominent research themes. International Journal of Tourism Research, 1(3), 167-193.

Lashley, C., \& Morrison, A. (2001). Introduction BT - In Search of Hospitality (pp. xv-xvi). Oxford: Butterworth-Heinemann.

Lefever, M. M., \& Withiam, G. (1998). Curriculum review. The Cornell Hotel and Restaurant Administration Quarterly, 39(4), 70-78.

Lin, S.-C. (2002). Exploring the Relationships Between Hotel Management Courses and Industry Required Competencies. Journal of Teaching in Travel \& Tourism, 2(3-4), 81-101.

Lucas, R. (2004). Employment relations in the hospitality and tourism industries. London, UK: Routledge. M.Ariffin, A. A., Maghzi, A., \& Aziz, N. A. (2011). Guests, Understanding hotel hospitality and differences

betweenlocal and foreign. International Review of Business Research Papers, 7(1), 340-349.

Mandabach, K. H., Vanleeuwen, D., \& Bloomquist, P. (2001). Hospitality Technology Education: Student Successes in Mastering the Hidden Curriculum. Journal of Hospitality \& Tourism Education, 13(1), 49-56. Marchante, A. J., Ortega, B., \& Pagán, R. (2006). Determinants of skills shortages and hard-to-fill vacancies in the hospitality sector. Tourism Management, 27(5), 791-802.

Mars, G., \& Nicod, M. (1984). World of aaiters. Crows Nest: Unwin Hyman.

Mayhew, K., \& Keep, E. (1999). The assessment: knowledge, skills, and competitiveness. Oxford Review of Economic Policy, 15(1), 1-15.

Mish, C. F. (1997). The Merriam Webster dictionary. Springfield: Merriam Webster Incorporated.

Mudor, H. (2011). Conceptual framework on the relationship between human resource management practices, job satisfaction, and turnover. Journal of Economics and Behavioral Studies, 2(2), 41-49.

Mullins, L. J. (1981). Is hospitality unique? Hospitality, 30-33.

Nankervis, A. R., \& Debrah, Y. (1995). Human resource management in hotels. Tourism Management, 16(7), 507-513.

Netter, T. (1998, December). Grim and getting grimmer. World of Work, 27, 6-12.

Oliver, K. M., Russel, C., Gilli, L. M., Hughes, R. A., Schuder, T., Brown, J. L., \& Towers, W. (1997). Skills for success in Maryland: Beyond workplace readiness. In H. F. O’Neil (Ed.), Workforce readiness: Competencies and assessment (pp. 47-76). New Jersey, NJ: Lawrence Erlbaum Associates.

Peacock, N., \& Ladkin, A. (2002). Exploring Relationships between Higher Education and Industry. Industry and Higher Education, 16(6), 393-401.

QFinance. (2009). Performing a Skills Gap Analysis. Retrieved from http://www. financepractitioner.com/performance-management-checklists/performing-a-skillsgap-analysis 
Retail, S. (2004). Market assessment for the UK retail sector. Retrieved 14 May 2017, from www.skillsmartretail.com/

Saayman, M., \& Geldenhuys, S. (2003). An analysis of skills required for selected sectors of the tourism industry. South African Journal for Research in Sport, Physical Education and Recreation, 25(1), 83-95.

Schuurman, L. (2004). An evaluation of tourism training: A conceptual analysis. Cape Town: Cape Technikon. Shaw, G., \& Williams, A. M. (2001). Critical Issues in Tourism: A Geographical Perspective (2nd ed.). Oxford:

Wiley-Blackwell.

Sinclair, K. E. (1997). Workforce competencies of college graduates. In H. F. O’Neil (Ed.), Workforce readiness: Competencies and assessment (pp. 103-120). New Jersey: Lawrence Erlbaum Associates.

Skills, A. (2012). Real estate and facilities management sector skills assessment. London, UK.

Soanes, C., Hawker, S., \& Elliot, J. (2006). Paperback Oxford English dictionary. New York, NY: Oxford University Press.

Swanson, R. A., \& Holton, E. F. (2009). Foundations of Human Resource Development. San Fransisco: Berrett-Koehler Publishers.

Weilbaker, D. C., \& Crocker, K. (2001). The Importance of Selling Abilities in Corporate Hospitality Sales to Corporate Customers. Journal of Hospitality \& Leisure Marketing, 7(4), 17-32.

Wood, A. (1997). Openness and Wage Inequality in Developing Countries. World Bank Economic Review, 11(1), 33-57.

Zorin, I. V. (2001). Problems with developing internal tourism. In Collection of Research Articles (Inter-regional conference). Dmitrov.

\section{Authors Note}

The authors would like to thank the National Bank for Agriculture and Rural Development (NABARD) for funding this research project.

The authors are also thankful to the two anonymous reviewers for useful suggestions made on the previous version of this manuscript.

Correspondence concerning this article should be addressed to Suprabha K. R., School of Management, National Institute of Technology Karnataka, Surathkal, Mangalore - 575 025, Karnataka, India. Email:suprabha@nitk.ac.in

\section{Biographical Notes}

K. R. Suprabha is an Assistant Professor in School of Management, National Institute of Technology Karnataka. She has published articles in national and international journals. Recently, she has been working on labour issues in the hospitality sector in South India, funded by the National Bank for Agriculture and 
Rural Development. The present paper is the outcome of the above said project. She has coordinated several research projects in the area of poverty elevation, rural development, and women empowerment.

Krishna Prasad is an Assistant Professor in Justice K. S. Hegde Institute of Management, Nitte. He is currently pursuing his $\mathrm{PhD}$ in the area of Foreign Exchange Risk Management at the National Institute of Technology Karnataka, Surathkal. His area of research includes Risk Management, Corporate Governance, and Reporting Practices and Taxation.

Shridev is a research scholar at the School of Management, National Institute of Technology, Karnataka, India. His area of research is in the field of financial distress and default. He has also served in the South Indian Bank as a manager for more than five years. 